\title{
Between angels and demons: boundary symbols and symbolic politics in the Danish management of aliens
}

UIf Hedetoft institutleder, professor, dr. phil., SAXO-Instituttet, Københavns Universitet

\section{Objective}

Political symbols are a central part of policies of nationalization, immigration and integration in all countries, Denmark not least (Adriansen 2003; Stoklund 2002). Here they have proved so significant that after having been shaped and refined by the country's public debates, the media and political actors of varying hue for years, they have developed into a comprehensive repertoire of symbolic politics, a political culture rooted in and focussed on the maintenance of a perceived mono-cultural Danishness - in an increasingly interdependent and culturally diverse global context.

This article will engage with some of the political symbols and the symbolic politics (SP) which over the last decade have been developed in aid of the confirmation and reassertion of the borders between 'them' and 'us' in Denmark - and the ways such border and boundary symbols get deployed as discursive weapons in the fight against a threat which sometimes is demonized as both internal and external, but more and more frequently get played down, modified or even neutralized in the context of more pragmatic perceptions of integration.

In consequence of this current tendency, the paper will finally discuss not only the symbolic politics of boundaries, but also new developments constraining the usefulness of old-style symbolic politics while in the process introducing new boundaries and different political priorities.

\section{Political symbols, symbolic politics and the Other $^{1}$}

Symbolic politics (Adelman 1985; Hedetoft 1998 \& 2007: Kertzer 1988; Sears 1993; Voigt 1989) rests on the practical deployment of a variety of signs embedded in the collective cultural and psychological repertoire of na- tions (Billig 1995; Boswell \& Evans 1999; Hedetoft 1995; Herzfeld 1992; Löfgren 1989; Nora 1984-91). Umberto Eco (following Charles S. Peirce) once defined a sign as 'everything which can be taken as significantly substituting for something else' (Eco 1976: 7). Signs - and symbols in particular - are inherently relational. They refer to, stand for, and connote a referent which is external to the sign, whose properties may be factually unrelated to the autonomous meaning charge of the sign itself, and which, as Eco points out, 'does not necessarily have to exist' (ibid.), except in the collective imaginary of the group in question. Symbolic representations especially are characterized by such 'non-motivated' links between sign and referent. A 'rose', per se, has little to do with 'love'; a 'lion', as such, is unrelated to 'courage'; and a red rectangular piece of cloth with a white cross superimposed reveals no trace of Danish nationalism. Yet the links are there; we know, by tacit agreement and conventional use, that a rose 'is' a symbol of love, a lion of courage, and the red and white piece of cloth of the Danish nation state. In Michael Walzer's classic wording on the nation-state and symbolism, the nation 'is invisible; it must be personified before it can be seen, symbolized before it can be loved, imagined before it can be conceived' (Walzer 1967: 194). It all seems so natural, although it is embedded in codes - second-order signs - that we need to be able to decipher in order to make sense of them. ${ }^{2}$

SP depends for its success on the same kind of process - a process of osmosis producing, pace Eco, 'a socially shared notion of the thing that the community is engaged to take as if it were in itself true' (ibid.). It is an exercise steeped in signs and discourses intended to produce consensual agreement between representers (political agents, the media) and represented (peoples, electorates, ethnic groups). The precondition of such identification is that 
relations and states of affair are successfully naturalized through narratives and fictions (myths, legends, rituals) of the non-political state (Anderson 1983/1991; Hedetoft 1995; Kapferer 1988). This is the paradox of all SP: as a political activity it is crucially dependent on mobilizing images of the 'state of nature', of organic relations, historical continuities, and anthropological invariables - in other words on coming across as the natural articulation of the most fundamental desires and ambitions of people.

This is in the ideal world, however. In reality, contexts and causes of SP are frequently conflictual and riddled with unresolved tensions, casting either the people (topdown discourses of unreasonable popular demands) or the state (bottom-up discourses of elite failure) as problems for national unity. Conversely, it is precisely on the background of such conflicts that SP is mobilized in order to reinstate order and again 'make sense' of the (national) world by calling on time-honoured virtues, morals, values, and achievements of the collectivity - or to attempt to forge a new and better community within or across traditional political boundary-lines (which in turn will tap into - or engineer - its own myths, legends, and origins). The success or failure of such discourses depend on the one hand on objective conditions and contextual factors (external relations, power struggles, (in)stability, interest constellations, resources), but also on the degree of rhetorical persuasiveness and leadership projection (charisma and trustworthiness) of core political actors; on timing and strategic orchestration (rational deployment of authority); and on how well the symbolism employed aligns itself with positively perceived images and cultural properties of the nation (traditionalism and continuity). Or differently expressed: on the efficient application to the 'naturalist' universe of symbolic politics of Max Weber's three forms of authority: traditional, charismatic, and rational-bureaucratic (Weber 1948/1994).

At the center of many such efforts we invariably encounter examples of the symbolization of the boundary between 'us' and 'them'. This can take a variety of forms, ranging from signs that directly try to capture the postulated essence of physical-geographical borders (or their gradual erosion) to much more subtle and 'unmarked' representations of cultural, phenotypical, political or ethnic boundaries - e.g. in the shape of symbolic dualisms such as 'darkness' vs. 'light' (: read oppression versus freedom, East versus West) and attendant twilight zones between them. More on this below. What needs to be stressed at this point is that, in keeping with the nature of second-order signs, boundaries - lines separating the positively valorized subject from the more or less negative object - will rarely be represented as such but rather in the form of e.g. displaced images of personal properties, civilizational attributes, collective belief-systems, or projected consequences.

Thus, the rationale of SP is multiple and constitutes a permanent companion of more rationally informed initiatives in modern political regimes, since it is directed toward affirming or strengthening identities rather than being concerned with the pursuit of interests, or differently put, with pursuing interests in the form of normative or value-oriented politics. SP is therefore more affective than cognitive, more rhetorical than substantive, more normative than pragmatic, more ideational than material - but more often than not has profound political and material consequences on real policies practically pursued. In functional terms, it is aimed at the maintenance of political legitimacy. Hence, SP consists of exercises in persuasive communication and, sometimes, political mobilization (rallying sympathies and mobilizing against threats), exercises aimed at reconstituting the political and cultural boundaries between 'us' and 'them', angels and demons, inclusion and exclusion, homeness and foreignness. It is concerned with drawing and redrawing boundaries, setting up zones of engagement, mediation or 'demilitarization' in between, recapturing or renegotiating territory - cultural, geographical, psychological, or all of these at the same time. It is rather instructive that 'territory' (ours, that is - appropriated and domesticated violently to the exclusion of the Other) is the close etymological cousin of 'terror' (Gottmann 1975; O'Leary, Lustick \& Gallaghy 2001: 3).

It follows that SP is most prominent in situations of instability, perceived threat, social anomie, or other situations characterized by conflict and tension. It is most markedly, though far from exclusively deployed by minority groups in claims-making and highly politicized contexts, as Canadian Prime Minister Jean Chrétien's impassioned plea (in itself not devoid of SP rhetoric) from 1996 - in a situation when separatist tendencies in Quebec and among indigenous peoples were threatening the cohesiveness of the country - makes it clear:

'Our country is sick of symbolic politics, and (...) it may die from this disease. In symbolic politics, unlike ordinary politics, everything becomes a matter of black and white. Positions are turned into sacred ideals on which no compromise is possible. (...) So I would ask all of us in the next few months to be careful in our assessments and our rhetoric, to avoid emotionally laden language and symbolic politics that could destroy this country. We cannot allow Canada to die of symbolic politics.' (Chrétien 1996) 
Appealing to cohesion, defense of identity and territory, or historical traditions and cultural homogeneity is clearly most acutely called for when the community or the state is imagined as threatened. More specifically, we can distinguish between three modes of SP: the SP of securitization and existential threat, triggered by predicaments of war, sudden and thoroughgoing political or economic crises, social cleavages, or natural disasters; the SP of systemic change, drawn on in situations where political regimes are facing serious transformative challenges of a social, economic, or political nature, implying new forms of adaptation and inner cohesion, and hence a rethink of identity structures and relations of trust; and the SP of civic discontent and moral emergency, activated, for instance, in connection with responses to immigration, marginalization and erosion of national sovereignty. ${ }^{3}$ The three modes are not always clearly distinguishable in political and social practice. Nevertheless, it is useful to think of them as discrete modes fitting different situations and to a large extent determining how the cultural and aesthetic repertoire at the disposal of SP is deployed in specific contexts. In the following, the main focus will be placed on the third and last of these modes: the SP of Danish immigration discourse, the imagery it employs to conjure up ideas of eroding borders and cultural emergency, and its current trajectory.

\section{The symbolic politics of immigration and the Danish case}

In principle, immigration in both political and cultural terms is a serious challenge to all national communities and states, because it defies some of the most basic assumptions on which European nation states are based and which facilitate interaction, trust, and solidary relations between politics and people: clear boundaries, ethnic homogeneity, a common history and culture, same language, shared socialization and political culture, consensual values etc (Gellner 1983; Goodhart 2004; Hall 1998; Hedetoft \& Hjort 2002; Hobsbawm 1990; Nussbaum 1996; Renan 1882/1990). In fact, immigration (particularly certain groups of immigrants in sizeable numbers) challenges the successfully naturalized state (Denmark being a prime example). For the same reason, the inevitable and sizeable demographic movements which nevertheless occur across the political and cultural boundaries structuring our worldviews and social practices must necessarily provide fertile ground for symbolic politics - and for constantly reactivating the cultural stock-in-trade by appealing, often in outspokenly populist forms, to the fears, loyalties, and moral habitus of nationalist audiences. Migration, especially when it is sizeable and visible (read: derives from areas where people's physiological features make them stand out) and can be represented as itself a sign of more comprehensive threats (read: globalization, Islam and extremism), is thus a universal breeding ground for securitization discourses of moral panics, apocalyptic demagoguery, and discourses of ethnic purification, but also for domestic dissension and international criticism based on the symbolic politics of universal rights and minority protection. Immigration (and its corollary, cultural pluralism) ruffles the feathers of the national compact and its arduously achieved common identity. It triggers a variety of political reactions (e.g. neo-conservatism), debates and discourses (eg social cohesion), and policy initiatives (e.g. practical integration measures; border control) intended to either mobilize people around and by means of the national narratives or to soothe the same people by appealing to their humanitarian sympathies while insisting that multicultural solutions do not necessarily undermine the cohesiveness of the community, but should be regarded as socio-economic supplement or cultural enrichment.

Indubitably, however, it is the SP discourses of the former variant - populist policies of identity appealing to people's national 'instincts' - that attract most public attention and political support (Stolcke 1995; Wodak $\&$ van Dijk 2000). In these discourses, immigrants are framed as problems which threaten the ideally clear-cut and nicely-drawn boundaries of national communities (Berger 1998; Parekh 2000), by failing or refusing to 'integrate' properly, living off welfare benefits rather their own independent income, setting up 'parallel societies' (also called ghettoes), representing cultures of crime, violence, and paternalism that run counter to democratic norms, or just failing to display the engagement, participation, economic initiative, loyalty, and gratitude that are to be expected of newcomers. In the terms of a political rhetoric projecting (even sometimes freely constructing) such challenges, the national community must defend itself against cultural encroachments and impending erosion (Ascherson 2004; Goodhart 2004).

In turn, the result is frequently (and increasingly) rallying cries for more proactive cultural or value-oriented debates, reminding people of the need to come to their senses before it is too late, appealing to (other) politicians to take immediate action, and providing the moral background and legitimation of remedial practices in the form of restrictive immigration and repatriation laws as well as tougher integration measures (Gammeltoft-Hansen forthcoming; Guiraudon \& Joppke 2001; Schendel \& Abraham 2005; Vertovec \& Wessendorf 2010). In this way, symbolic politics, normative culturalism, and border policies complement each other in the case of immigration. 
The following illustrates in exemplary manner such migration-based and boundary-sensitive SP discourse, taken from a debate in the Danish Parliament (April 2002) on a proposal for the conferment of citizenship to named immigrants.

"I recently heard about a school principal from Nørrebro [inner-city area of Copenhagen]. One day she met the father of some Turkish children in her school, accosted him and complained that his chidren did not speak Danish: 'When they live in Denmark, they must speak Danish'. The Turkish father looked at her and replied, 'Do we live in Denmark? No, we live in Mjølnerparken [concentration of council housing with a majority of ethnic-minority residents], and here only $2 \%$ of the residents are Danish. No, we do not live in Denmark.' (...) Indeed, it is becoming a very strange thing to be a Dane in this country, for step by step, bit by bit Danes are being turned into strangers in their own land. It is a historic and national disaster, which is taking place. It is the slow extinction of the Danish people that Parliament is allowing to happen. For let us not forget who is responsible for the growing alienation of Danes in Denmark: It is this very Parliament. [The proposal before us is] irresponsible, immoral, treasonous." (Danish Parliament 2002)

The speaker, Søren Krarup, hails from the Danish People's Party, which has, more than any other party in Denmark, projected itself on an anti-immigrant agenda and since 2001 has provided parliamentary support for the Liberal-Conservative government. The debate as a whole lasted for the better part of two days and was liberally spiced with often quite detailed and abstruse references to and interpretations of the historical origins, foundational texts, myths of unity, and cultural values of 'Danishness' (Gundelach, Iversen \& Warburg 2008; Hedetoft 2007; Smith 1986), although a majority, not surprisingly, took issue with the direct attack against Parliament for dereliction of its national duty and although the political conclusions drawn by different parties in terms of supporting the bill or not differed significantly. In fact, most members turned out to be in favour of 'naturalizing' the 6.163 people that it concretely concerned. Nevertheless, the discursive tenor of the debate was set by the symbolic politics of identity embedded in the quotation and almost all addressed the cultural concerns and political charges contained in it on a note of respectful recognition and sympathy as regards the goal of national unity and the worries about failed integration that it articulates.
There was, in other words, if not full agreement, at least widespread consensus that immigration / immigrants constitute a serious challenge; that emergency discourses are not completely misplaced; and that policies based on values, traditions, and the history of unitary identity were called for. The agenda had clearly shifted from one mainly focused on instrumental, problem-solving approaches to integration issues to one deeply infused with the politics and negotiations of symbolic boundaries and belonging. The border is here perceived to have shifted from the external border to domestic territory, which in turn is argued to have been colonized by people of non-Danish extraction. 'Foreignness' is thus not only in our midst as a cultural presence, but as a piece of Danish land as well.

Immigration as a policy field and a trigger of symbolic politics of the moral emergency type is interesting because it straddles three major modalities of nation/ state interaction (Hedetoft $2004 \& 2007$, 594-96): the imperative (the top-down nationalization of the masses; e.g. Mosse 1975), the indicative (the banality of successful national identity; e.g. Billig 1995), and the subjunctive (the national and/or political dream of sovereignty; e.g. Gibernau 1999). It is mostly based on the indicative as the point of factual or alleged departure, but on this bases weaves imperative discourses ('they' must now be integrated and assimilated, and we need some tough talk and policies to achieve this state of integration and newfound cohesion) together with subjunctive ones mainly targeted at the ethno-cultural core community (if only we were back to the good old days - alternatively let us do all we can to reconstitute ourselves as a sovereign and cohesive entity and return to 'banality'). In this way, the SP of immigration, by conjuring up many small emergencies and moral panics, works not just as a discourse of conflict and controversy, but also as a constant unifier, by giving political actors the opportunity to reiterate the basis and boundaries of commonality and make full use of the national repository of cultural symbols.

The next section will show that symbolic politics based on antagonistic thinking and catch-all symbols of Otherness persists, but also that new signs and discourses are beginning to appear, developments indicating new boundaries, new visions and experiences of integration, a novel integration reality, and in some measure a learning process among political actors and the public at large following the Cartoon Affair and its global aftermath (Hedetoft 2006). 


\section{Burkas and babies - from experience to innocence?}

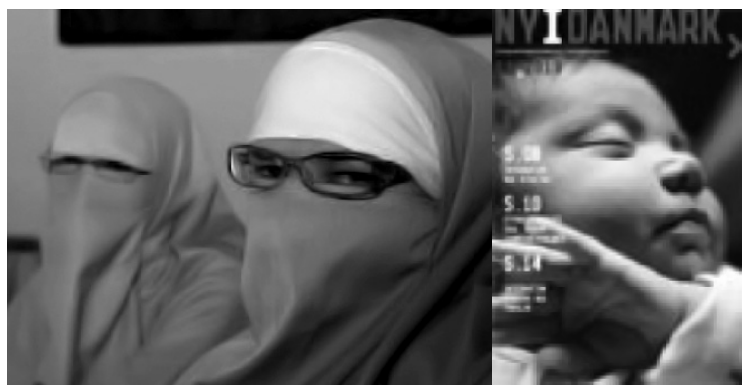

The two images above are symbolic representations of recent debates and developments in Danish attempts to conjure up threats to Danishness from immigrant cultures and to reassert the natural basis of Danish identity in conjunction with integration. At the same time they subtly indicate a significant recent change in and modification of the symbolic boundary between 'them' and 'us' (in turn reflecting an underlying change of economic and political conditions), the former image ('experience') expressing the traditional preference for exclusion of the alien in our midst, the second ('innocence') depicting an alternative modality of inclusion and almost naivistic assimilation of the new-born Dane of foreign extraction the alter ego of boundary-drawing, which simultaneously is a warped reflection of real changes in the integration and participation of 'new Danes' on the labour market and beyond. This will be further addressed in the next section.

The first picture symbolizes the so-called Burka debate, which unfolded in the autumn of 2009. An extension of the protracted debate about the Muslim veil in Denmark as well as many other European countries, the Burka (and the Niqab) was first posited as a real integration problem by leading members of the Conservative Party, in an attempt to capitalize on anti-immigrant sensibilities among citizens and to capture voters from the Danish People's Party by hijacking their most prominent political cause and turning a negative tide for the Conservatives. There was no specific issue at stake or domestic debate going on making it imperative let alone worth while to produce an image of emergency and insecurity (the Burka had already been introduced in France as a potential social problem, but this must be regarded as a welcome condition of rather than a reason for bringing up the topic in Denmark). So, virtually out of the blue the Conservatives, probably looking for a cause that might enhance their popularity and public visibility, proposed an unqualified legal ban on the Burka and the Niqab, since they allegedly encapsulated everything that 'we' are not: oppression, female subjugation, un-freedom, lack of democracy and Islamic despotism. Simultaneously, the implicit assumption was that this was a real growing problem of considerable magnitude.

It soon emerged that neither had the Conservatives had this initiative approved by their partner in Government, the Liberal Party, nor had they investigated the real extent of the problem, let alone checked the legal status or ramifications of their proposal - which eventually was deemed unconstitutional. The proposal therefore immediately gave birth to a heated debate with the Conservatives on the defensive, being hard pressed for a political justification for launching into this hornet's nest of political symbolism.

In order to restore order and unity to the Government and probably save the Conservatives from a humiliating retreat, the Prime Minister (Lars Løkke Rasmussen from the Liberal Party) decided to set up a 'Burka Committee' with the remit to analyze the problem and report back to him in due course.

If this was a pacifier intended to kill the debate and get on with business (see next section), the tactic was partially successful for a time. But the debate was rekindled when the 'Burka Report', ${ }^{4}$ which the Committee had commissioned from the University of Copenhagen, was made public and documented beyond reasonable doubt what most had suspected, namely that in the entire country very few people wore the Niqab and only a handful or less the Burka.

The reaction by the Conservatives (and the Danish People's Party, which in the meantime had warmed to the idea), was not to pull back, but to claim that the report was unscientific, bungled, useless, and the researchers not worth their money. In any case, it was argued (and the Prime Minister supported this position), the problem was not the quantitative extent of the problem (although this was precisely what the report had been asked to chart), but the very existence of these pieces of headcloth and what they symbolized.

In this context, the interesting point is that the Burka (or rather, the image of the Burka) is systematically deployed as a symbolic boundary-marker: something that physically separates us from them, individual identity from anonymous collectivity, communication from isolation, familiarity from peculiarity. The Burka comes to symbolize a refusal to integrate and participate in civic society, replacing the traditional phenotypical inferiority markers of, for instance, black skin or plump negroid features. The Burka - or just the imagined Burka, if it refuses to materialize in real life - turns into a kind of negative phenotype of Islam, the symbol par excellence demonstrating that although lots of 'them' walk 'our' streets and 
reside in 'our' neighbourhoods, there is an unbridgeable divide. The Burka transforms from a religious-cum-cultural garment for 'them' into a political weapon for 'us'.

That at least was the intention. The result was slightly different, and is closely connected to the reason a Burka 'panic' had to be invented - a symbolic construct ex nibilo rather than a positive fact politically instrumentalized: integration and participation, inclusion in other words, are proceeding apace in Denmark (see further below); the Cartoons have moved into the realm of high politics and are no longer very useful for domestic purposes of cultural marginalization; ${ }^{5}$ and political Islamism is, if not absent in Denmark, at least a fringe phenomenon, separated from mainstream Muslims' everyday activities and identities. The implication is a change of political symbolism too. The symbolic politics of borders does not disappear, but old, generalized, all-exclusive borders against immigrants as such multiply and bifurcate into on the one hand the oxymoron of 'boundary symbols of integration' (see below) and on the other militarized symbols of (in)security, panic and emergency, connected partly to terrorism and the Danish war efforts in Afghanistan, partly to ongoing domestic gang and drug warfare, comprising drive-by shootings and other violent showdowns over the distribution of illicit drugs (both territory and revenue) between motorcycle gangs (mainly Hell's Angels) and criminal groups of 'immigrant' thugs, predominantly in Copenhagen.

Old dichotomies reappear in new guises. We now find official symbols of peaceful togetherness hand in hand with hard-liner gestures of separation, exclusion and open contempt for the alien Other. The new border is one between the good and the evil Other, angelic versus demonic difference - an overlay on the basic antagonism between us and them. We know the latter well enough - exemplified not just by the Burka, but notably by the Cartoon image of the prophet with a bomb in his turban, which has now entered a new phase and taken its place within a new configuration of boundary-drawing. The former, however, is a relative newcomer on the stage of symbolic politics and is well captured by the second image at the top of this section - which appeared recently on as the front-page illustration of the magazine titled NyIDanmark [New in Denmark], no. 1, 2010, published regularly by the Ministry of Refugees, Immigrants and Integration.

The baby, peacefully at rest, in the context of the specific institutional and communicative setting unequivocally represents the idea of a just as peaceful, organic and unproblematic an integration process through Danish socialization from birth. Interestingly, at first glance the baby is depicted as an autonomous organism, alone, with- out parents or just a mother cradling and nursing it - as if the invisible boundary-line between a somewhat non-integrated mother and her integration-prone offspring has found its way into the image as an absent zero signifier. Thus at first blush the picture is an essentialist representation of untarnished assimilation material ready to be moulded into 'Danish' shape. This is the counter-image to the traditional and negative perception of immigrants as threats to the natural (depoliticized) state.

However, the more functional, realistic and down-toearth alter ego representation of the front-page image has found its way into the magazine itself. The front-page infant anticipates the thematic focus of the issue: 'toddlers'. For, as the subtitle states in so many words, 'integration starts at birth'. The thematic section features inter alia a prominent article unravelling the narrative of a single Muslim role-model mother of six, quoted for saying that 'my kids must be given the best possible start'. She has fought and eventually divorced a paternalistic, traditionalist Muslim husband, who, unlike the mother, did not think it desirable to place their kids in public child care or for that matter allow them to entertain any contact with Danish institutions of socialization. The 40-year-old role model, on the other hand, insisted and finally got her way, though she allegedly had to struggle not just against her ex-husband, but also the prejudices of the Danish caregivers. 'You can hang on to your core Muslim values and get integrated from day 1 - as long as you cooperate well with institutions', as she is reported to have said in a foregrounded statement.

The functional pragmatism of this position - complementing the organicism of the front-page photo - is pictorially represented by a snapshot showing her - wearing a headscarf, but no Burka - carrying her three-year-old son on her lap. They have both successfully challenged the boundary between us and them, having chosen sides wisely while leaving the former husband and father behind on the other side. The inclusion/exclusion process is no longer a simple separation between ethnic others and ethnic Danes, but increasingly takes place within the category of the Other, pragmatically at first perhaps, but at a later stage the reward of total assimilation - the front-page lure, where the boundary has not just been modified but has evaporated - waits around the corner.

This novel discourse is interesting mainly for three reasons: first, it imagines a new social reality of us and them, even an ideal reality where a substantial part of them (notably women, who were often vilified in previous alien stereotypes) become active instruments of integration; second, integration is portrayed as a less-than-purist process, where social participation and cultural diversity are acknowledged to co-exist (running against the tradi- 
tional Danish mono-cultural, assimilationist grain); and third, it rather accurately reflects a new reality of shifting and dislocated boundaries, less overt politicization of the field, and a well-documented greater degree of parity between old and new Danes as regards participation on the labour market, in civil institutions, in the housing sector, in (higher) education and in public debates - as e.g. Hans Lassen has convincingly argued in a recent series of articles. ${ }^{6}$ Immigrants and descendants are beginning to emerge in labour-market, housing, electoral and crime statistics as almost average Danes, and particularly the wide gaps that used to exist as regards occupational frequency between ethnic Danes and newcomers from non-Western countries are closing fast - whether or not this is the result of policies pursued by the government, of more realistic attitudes adopted by new generations and 'types' of minority Danes in a novel economic context, or of a normal integration and adaptation rhythm which commonly takes a few generations to set in - or, most likely, a combination of all three, In other words, the discourse implicitly points toward the boundaries (=limits) of symbolic politics in this area, the point where the politics of symbols and the demonizing symbolization of an impermeable us/them boundary is no longer useful (perhaps even dysfunctional) and is therefore being replaced by more 'innocent' and utilitarian concepts.

A few additional reflections on this important theme in Denmark and in the wider global context are appropriate at this stage of the argument.

\section{The boundaries of symbolic politics: on sym- bolism and Realpolitik}

The high-profile politicization of the immigrant domain which has characterized Danish politics for many years and has set the agenda for the securitization of the field and the attendant SP emergency discourses of threatened boundaries and identities is markedly on the wane. This development represents partly a process of 'normalization', where immigration issues are starting to become treated as just any other ordinary political problem and less as the election-winning trump card (which it has been for the past decade), and partly as a process of shifting priorities, since the crisis has made it clear that crisis problems of rising unemployment, faltering economic growth and undesired outsourcing to the Far East cannot be resolved by blaming the alien immigrant or by managing immigration differently. Thus, emergency talk within a changing political culture has become displaced from the SP of immigrant demonization to problems of small-state adaptation to a new global economic and political order. The combined effects of 'normalization' and 'displacement' (bolstered by increased immigrant participation in Danish societal affairs), 'effectiveness' and 'legitimacy' (Lipset 1963: $64 \mathrm{ff}$.) of political rule, are to minimize the need for the SP of paranoid boundary-drawing, since immigrants and immigration no longer lend themselves ideally as objects of rhetorical strategizing and political positioning. Immediate, hard-core interests override the symbolization of identities.

The interesting corollary of these reflections is that tough anti-immigrant discourses and Othering strategies connected to them are manifestations of phases and situations typified by a surfeit, not a deficit of political, cultural and economic capital - which is how problems in this field have normally been orchestrated. In the Danish context, this must be understood in the specific historical context of 'right-sizing' and 'right-peopling' the national territory and the Staatsvolk (O'Leary, Lustick \& Callaghy 2001: 15-73) on the background of a long history of national defeats, territorial diminution, unfortunate international alliances and even loss of sovereignty (Adriansen 2003; Kaspersen 2008; Østergård 2006). These threats were gradually and, as it turned out, rather successfully overcome in the post-war years, where Denmark learnt to adapt internationally while building welfare, solidarity and consensus domestically - on the basis of a decidedly 'monocultural polity' with a clear and all-dominant ethnonational core giving no political concessions (specific minority rights or descriptive representation) to other ethnies (Campbell, Hall and Pedersen 2006; Hedetoft 2010). The historical failure of 'right-sizing' found its complement in attempts to at least 'right-people' the remaining national territory. In other words, Denmark's post-war successes were founded on the solid ground of ethnic homogeneity, laying the foundation of anti-immigrant (diversity) anxieties and demands for assimilation, and making it understandable why vote-catching strategies and symbolic politics connected to immigrants were never far away, bursting into full bloom in the mid-1990s (when, interestingly, Denmark's economy was booming, not declining). The combination of previous failures (many of them dating back to a multinational and multicultural past prior to the historic defeat to Prussia in 1864) and a successful mono-cultural aftermath set the stage for pathdependency reactions, even of a demonizing, rigid and racist kind. The symbolic politics of immigrant Othering, for that reason, bears interesting reminiscences to the symbolic politics often adopted by minorities for claimsmaking purposes in contexts where they need to win the ear of political majorities seen to dominate and impose their cultures on them (e.g. in Canada, New Zealand and Australia); on this count, Danes have reacted in the vein of and inspired by their historically perceived minority status vis-a-vis Germany and other larger international 
players. The Volksgeist replete with historical memories of misfortunes and menaces of foreign origin, it is hardly surprising that in a more successful phase attributed to cultural consensus and 'horizontal solidarity' via welfare institutions, 'right-peopling' - in a country invariably seeing itself as 'little Denmark' - has been connected to 'ethnic domination' by Danes and Danish culture, in a process reminiscent of historical vindication. In this light, it is, if not conceptually correct at least metaphorically apt that Danes are frequently categorized as a tribe (Mellon 1992; Gundelach 2002).

The turbulence that the Danish immigration debates and policies have undergone over the last 20 years or so should in no small measure be analyzed in this context. It is obvious, on the other hand, that the politicization of the field in this manner is crucially dependent on being able to refer to (or better: conjure up in symbolic ways) successes that stand to be forfeited if immigrants either do not integrate better or stay away. In the current crisis, such strategies, if maintained and supported, would develop into outright fascism, and have for that same reason little purchase in Denmark, where the wish to celebrate Danish identity in quasi-mythical terms is offset by a just as outspoken pragmatism (Hedetoft 1995, 380 ff.), economically and politically. Hence the current normalization and 'depoliticization' tendency: the reality of globality has, in a manner of speaking, forced Danes and not least their politicians to review their strategies and top priorities, and here traditional boundary talk and kneejerk objects of demonization will not work and cannot be allocated a central role. Now it is truly 'the economy, stupid', and while the tough rhetoric of Othering, crisis and emergency has not entirely left the scene, it is now predominantly reserved for the high-politics domain of terrorism, security and border control. The demons are increasingly being represented as Al Queda-inspired puppets of evil intent, but there is no longer an invisible or explicit sign of equation between such present-day incarnations of fascist insanity and the ordinary run-of themill person of non-Danish extraction.

\section{Perspective: symbols and politics in the new migratory world order}

The Danish case is of course in some ways peculiar to Denmark. But in a European and global context of increased trans-state learning processes and policy convergence, it also contains some central references to more generic characteristics and developments. Multicultural policies and discourses have been widely overtaken by cohesion talk, which accepts diversity, but only if diversity can be instrumentalized in national contexts (Vertovec $\&$ Wessendorf 2010). Integration regimes, e.g. as reflected in proliferating 'points' schemes, ${ }^{8}$ increasingly make no bones about the importance they attach to measurable criteria of immigrant usefulness, and are much less concerned than previously with projecting themselves along humanitarian, moral or ethical lines - but also less concerned with beating the drum of demonization. Now the official message is more unequivocal, more cynical, but also less essentialist: 'they' need to prove their usefulness, and if they do, they are practically accepted as part of 'us' - at least for a time. For a corollary of integration, permanent residence, acquisition of citizenship, oaths of allegiance and ritualizing integration ceremonies is, everywhere, a new openness toward temporary migrants, time-limited utility and 'circular migration' (Neerup 2009; Ruhs \& Martin 2006). All the rest do not belong, should stay put where they are or at least well away from our shores - be they national or regional. In this world of utilitarian globalism, diverse, fluid and composite as it necessarily is, the need for essentializing Us/Them boundaries, ethnic identity constructions and a symbolic politics bolstering and legitimizing the in-group in the face of impending cultural threats is in less demand. It will never go away as long as the nation-state remains the key unit of the global order. But the more 'right-sizing' of the people becomes (widely accepted as) a question of political and economic utilitarianism, not just by the odd individual state but by international institutions and regimes across the board, drawing the line between acceptable and unacceptable others - quasi-scientifically 'right-sizing' the other in terms of 'integration potential' - will be a question of institutional technology and political managerialism far more than symbolically separating angels from demons.

\section{References}

Adriansen, Inge, 2003. Nationale Symboler i det Danske Rige 18302000. Copenhagen: Museum Tusculanum Press.

Anderson, Benedict, 1983/1991. Imagined Communities. London: Verso.

Ascherson, Neil, 2004. From multiculturalism to where? London: openDemocracy (www.openDemocracy.net), August 19.

Berger, Peter, ed., 1998. The Limits of Social Cohesion: Conflict and Mediation in Pluralist Societies. Boulder: Westview.

Billig, Michael, 1995. Banal Nationalism. London: Sage.

Boswell, David \& Jessica Evans, eds, 1999. Representing the Nation: A Reader. London and New York: Routledge.

Campbell, John, John Hall \& Ove Kaj Pedersen, eds, 2006. National Identity and the Varieties of Capitalism: The Danish Experience. Montreal: McGill-Queen's University Press.

Chrétien, Jean, 1996. Symbolic Politics. Speech held at Windsor, Ontario, April 28. Downloaded from www.pco-bcp.gc.ca/aia/default. asp ? Language $=E \&$ Page $=$ PressRoom $\&$ Sub $=$ Speeches $\&$ doc $=199604$ 28_e.htm\&PrinterFriendly=y) 
Danish Parliament 2002. Debate on Bill for the Conferment of Citizenship - Bill no. L 151(Forslag til lov om indfodsrets meddelelse), 2 April. Downloaded at www.folketinget.dk/samling/20012/salen/ L151_BEH1_45_1_(NB).htm

Eco, Umberto, 1976. A Theory of Semiotics. Bloomington: Indiana State University Press.

Edelman, Murray, 1985. The Symbolic Uses of Politics. Second and revised edition. Urbana: The University of Illinois Press.

Gammeltoft-Hansen, Thomas, forthcoming. Access to Asylum: International refugee law and the globalization of migration control. Cambridge: Cambridge University Press

Gellner, Ernest, 1983. Nations and Nationalism. Oxford: Blackwell.

Goodhart, David, 2004. 'Discomfort of Strangers'. The Guardian, February 24.

Guibernau, Montserrat, 1999. Nations without States. Oxford: Polity.

Guiraudon, Virginie \& Christian Joppke, eds, 2001. Controlling a New Migration World. London: Routledge.

Gundelach, Peter, 2002. Det er dansk [It is Danish]. Copenhagen: Reitzel.

Gundelach, Peter, Hans Ravn Iversen \& Margit Warburg, 2008. I Hjertet af Danmark [At the Heart of Denmark]. Copenhagen: Reitzel.

Hall, John, ed., 1998. The State of the Nation. Cambridge: Cambridge University Press

Hedetoft, Ulf, 1995. Signs of Nations. Aldershot: Dartmouth.

Hedetoft, Ulf, ed., 1998. Political Symbols, Symbolic Politics. European Identities in Transformation. Aldershot: Ashgate.

Hedetoft, Ulf, 2004. 'Different phases, different logics: nationalism and globality at two turns of century', Revue belge d'historie contemporaine, XXXIV, 4, 2004, 683-719.

Hedetoft, Ulf, 2006, 'Denmark's Cartoon Blowback', openDemocracy, March 1 (see www.openDemocracy.net).

Hedetoft, Ulf, 2007. 'Symbolic Politics and Cultural Symbols', in Jaan Valsiner \& Alberto Rosa, eds, The Cambridge Handbook of Sociocultural Psychology. Cambridge: Cambridge University Press.

Hedetoft, Ulf, 2010. 'Denmark versus multiculturalism', in Steven Vertovec \& Susanne Wessendorf, eds, The Multiculturalism Backlash. London: Routledge.

Hedetoft, Ulf \& Mette Hjort, eds, 2002. The Postnational Self: Belonging and Identity. Minneapolis: University of Minnesota Press.

Herzfeld, Michael, 1992. The Social Production of Indifference. Chicago and London: University of Chicago Press.

Hobsbawm, Eric, 1990. Nations and Nationalism since 1780. Cambridge: Cambridge University Press.

Kapferer, Bruce, 1988. Legends of People, Myths of State. Washington DC: Smithsonian Institution Press.

Kaspersen, Lars Bo, 2008. Danmark $i$ Verden [Denmark in the World]. Copenhagen: Reitzel.

Kertzer, David I., 1988. Ritual, Politics and Power. New Haven and London: Yale University Press.

Lassen, Hans, 2010. Den anden virkelighed. Tanker og tal om integrationen i Danmark [The other reality. Thoughts and figures about integration in Denmark]. Copenhagen: Information.

Löfgren, Orvar, 1989. 'The Nationalization of Culture', Ethnologia Europea XIX, 5-23.

Lipset, Seymour Martin, 1963. Political Man. The Social Bases of Politics. New York: Doubleday.

Mellon, James, 1992. Og gamle Danmark.... en beskrivelse af Danmark $i$ det Herrens År 1992 [And ancient Denmark...: an account of Denmark as it was in the year 1992]. Gylling: Narayana.

Mosse, George E., 1975. The Nationalization of the Masses. New York: H. Fertig.
Neerup, Stine, 2009. 'Temporary labour migration programmes: Australia, Denmark and the United States'. Unpublished manuscript. Melbourne: Monash University.

Nora, Pierre et al, 1984-91. Les Lieux de Mémoire. Paris: Gallimard.

Nussbaum, Martha, ed., 1996. For Love of Country. Debating the Limits of Patriotism. Boston: Beacon Press.

O'Leary, Brendan, Ian S.Lustick \& Thomas Callaghy, eds, 2001. Right-sizing the State. The Politics of Moving Borders. Oxford: Oxford University Press.

Østergård, Uffe, 2006. 'Denmark: A Big Small State', in John Campbell, John Hall \& Ove Kaj Pedersen, eds, National Identity and the Varieties of Capitalism: The Danish Experience. Montreal: McGillQueen's University Press.

Parekh, Bhiku, 2000. Rethinking Multiculturalism. Houndmills: Macmillan.

Renan, Joseph Ernest, 1882/1990. 'What is a nation?' [original title 'Qu'est-ce qu'une nation?'], in Homi Bhabha, ed., Nation and Narration. London: Routledge.

Ruhs, Martin \& Philip Martin, 2006. Numbers versus rights: trade-offs and guest worker programmes. COMPAS Working Paper no 40. Oxford: Centre on Migration, Policy and Society, Oxford University.

Schendel, Willem van \& Itty Abraham, eds, 2005. Illicit Flows and Criminal Things. Bloomington: Indiana University Press.

Schmitt, Carl, 1934/1996. The Concept of the Political, transl. George Schwab. Chicago: Chicago University Press.

Sears, David O., 1993. 'Symbolic Politics: A Socio-Psychological Theory', in Shanto Iyengar \& William J. McGuire, eds, Explorations in Political Psychology. Durham: Durham University Press.

Smith, Anthony D., 1986. The Ethnic Origins of Nations. Oxford: Blackwell.

Stoklund, Bjarne, ed., 2002. Kulturens Nationalisering [The Nationalization of Culture]. Copenhagen: Museum Tusculanum Press.

Stolcke, Verena, 1995. 'Talking Culture. New Boundaries, New Rhetorics of Exclusion in Europe'. Current Anthropology 16:1 (February), 1-24.

Voigt, Rüdiger, ed., 1989. Symbole der Politik. Politik der Symbole. Opladen: Leske + Budrich.

Vertovec, Steven \& Susanne Wessenforf, eds, 2010. The Multiculturalism Backlash. London: Routledge.

Walzer, Michael, 1967. 'On the Role of Symbolism in Political Thought.' Political Science Quarterly 82 (2), 191-204.

Weber, Max, 1948/1994. 'The Nation', in H.H. Gerth \& C. Wright Mills, eds, From Max Weber: Essays in Sociology. London: Routledge $\&$ Kegan Paul.

Wodak, Ruth \& Teun van Dijk, eds, 2000. Racism at the Top. Klagenfurt: Drava.

\section{Notes}

1. Sections 2 and 3 of this paper are a revised and adapted version of arguments offered in Hedetoft 2007.

2. Symbols are different from two other categories of signs: icons (e.g. photographic representations) and indexes (e.g. metaphors and metonymies), both of which carry inherent traces of the link between the image itself and its reality referent - in other words, are both somehow or other 'motivated' images. This implies that symbols are more open to cultural manipulation, political spin, and new applications in changing contexts.

3. Further on these three modalities and other theoretical reflections on symbolic politics, nationalism and transnational identity formation, see Hedetoft 2007. 
4. The full report can be accessed at http://www.e-pages.dk/ku/322/

5. The Cartoon Affair marks the high point of symbolic politicization of the undesired alien (read Muslim) other in Denmark. The time was ripe for it five years ago, the case condensing popular sentiments, media discourses and political agendas into one compact. The moral panic of those days bred on fertile soil: restrictive immigration policies, post-9/11 security anxieties, and a general neoconservative reaction against liberal nationalism and globalization. Today some of the after-effects of the Affair persist in Denmark (and copycat versions have popped up in Sweden, Norway, Holland and other countries too), but it is out of sync with the current Zeitgeist and the current normalization tendency of integration practices.

6. See Politiken, June 1-5, 2010. The articles were based on Hans Lassen's recent book, Den anden virkelighed. Tanker og tal om integrationen i Danmark [The other reality. Thoughts and figures about integration in Denmark - Lassen 2010]. See also the report IntegrationsStatus [Integration Status], January 2010, which the news agency Ritzau had commissioned from the survey house Catinét, as well as attendant media comments (http://www.infomedia.dk/ms/
Default.aspx). The report showed that immigrants and descendants are fast making their way into the middle classes, representing significantly increased social mobility; that the importance of religious identity is on the wane; and that minority women are doing particularly well in the educational system and on the labour market.

7. This point only partially applies to the DFF, who are desperately trying to keep the SP of immigration alive, since this is the core element of their electoral and parliamentary successes so far. Clearly, however, they are paddling against the current, as reactions to their recent proposal of raising the 24-year rule for mixed marriages to a 28 -year rule have demonstrated. The attempt by the Conservatives to capitalize on the decline of SP as regards immigrants has been analyzed above and failed for the same reasons.

8. Including Denmark, where a political deal between the government and DFF in March 2010 involves the introduction of a new points scheme, according to which permanent residence can only be achieved after the successful collection of 100 points. See e.g. Politiken, March 15, 2010, for the text and related comments. 